\title{
CARDIAC ARREST DURING INDUEED HYPOTENSION. CASE REPORTS
}

\section{S. 1. VANDEWATER, M.D. ${ }^{1}$}

THES IS A REPORT of two cases of cardrac arrest occurring during induced hypotension. The technique of induced hypotension, carries an increased risk to the patient, well documented by Little (1). This is a calculated risk which should be justified by the nature of the operation and the benefits to the patient.

\section{Case 1}

$M F$, female, age, 18 Diagnosis. cerebral arterio-venous malformation

History intermittent severe throbbing headaches for one year, patient suddenly became unconscious on the day prior to operation

Physical examination The patient was rather thun, drowsy but co-operative, neck stuff, dysphasic A bruit was heard over the left eye Rught facial weakness, nght hemıparesis, right extensor plantar resjonse Arteriogram showed a large Av malformation $\mathrm{n}$ the left frontal lobe near the m.d-line with evidence of clot formation Blood pressure was 120/60, Julse 100, haemoglobin 76 per cent Examination was otherwise negative

Premedicat on atropine $004 \mathrm{mg}$.

Anaesthesia thopentone $400 \mathrm{mg}$, succimethonum $30 \mathrm{mg}, \mathrm{N}_{2} \mathrm{O}$, trichlorethylene

Induced hypotension wàs inutiated, as the dura was opened, with a 0.05 per cent solution of Arfonad, and the blood pressure fell to and was mantaned at 75/50 for 134 hours. During this tume $425 \mathrm{mg}$ Arfonad and $50 \mathrm{mg}$. hexamethonuum bromide were given During evacuation of a large clot beneath the A.V malformation, cardiac arrest occurred. Cardıac massage was begun in 4 minutes and the heart, previously in standstill, began to fibrillate Cardiac massage was continued for 28 minutes, during which tme the systolic blood pressure was $100 \mathrm{~mm} \mathrm{Hg}$ Intracardiac adrenalin, $\mathrm{KCL}$, and $\mathrm{CaCl}_{2}$ resulted in no change. Four repeated attempts at electrical defibrillation made no change, but the fifth attempt, consistıng of five shocks led to the onset of a degular cardiac beat The operation was then carried to its conclusion, total elapse of time was $5^{1 / 4}$ hours During this time the patent received 2,000 cc. of blood and $500 \mathrm{cc}$. of plasma expander and an intermittent noradrenalin drip

\section{Postoperatively}

Immedrately pupils fixed and dilated (ArfonadP), comeal reflexes absent, both plantar responses extensor This was shortly followed by decerebrate ngidity.

24 hours nigidity decreasing, moving left arm and leg with stmulation, unconscious

5 days talking, but disonentated and aphasic, moving all four limbs spontaneously.

14 days able to answer questions intellicently, some right hemparesıs

21 days discharged, alert, cheerful, a Jle to write legibly, slow with conversation with slight dysphasia and some residual weakness on the right side, ECG normal.

6 months complete recovery, mentally alert and family report normal mental behaviour, persistent weakness in the right arm and leg, ECG norma]

15 months complete mental recovery and normal power in all muscle groups and able to carry on wrth high school education

1Department of Anaesthesia, University of Toronto, and Toronto General Hospital 


\section{Case 2}

E.C, male; age, 34. Diagnosis secondary melanotıc sarcoma, left inguinal glands History malignant melanoma iesected from left calf with dermatone graft, 3 months prior

Physical examination. Patient was well developed, physically fit, cardio-vascular and respiratory systems were normal $\mathrm{He}$ had firm enlarged glands in left gioin, and a recent skm graft left calf (hèaled) He had diabetes mellitus, mild, diet controlled until previous operation, now taking 15 units pz insulin daly Blood pressure was 118/70, pulse 72, haemoglobin 75 jer cent

Fremedication Demero. $100 \mathrm{mg}$, atıopine $006 \mathrm{mg}$

Anaesthesia thiopentone $500 \mathrm{mg}$, d-tubocurare $12 \mathrm{mg}, \mathrm{N}_{2} \mathrm{O}$, and tnchlorethylene

A radical block dissection of the left inguinal region was performed under hypotension induced with a 01 per cent solution of Arfonad, and the blood pressure was maintained at 75/58 for a period of 1 hour and 50 munutes. During this time $205 \mathrm{mg}$ Arfonad were required. The patient was lyng supine with the pelvis elevated On exposue of the common llac artery, the patient suddenly became pale and cardiac arrest was diagnosed At this time, the blood in the wound was pink and blood loss had been minumal Cardiac massage was begun within three minutes from the time of arrest and ventricular fibrillation ensued within moments. Attempted chemical defibrillation with $\mathrm{KCl}$ and $\mathrm{CaCl}_{2}$ was unsuccessful. Electrical defibıllation was successful and a regular rhythm was restored 40 minutes after arrest Myocardial tone was weak but improved immediately with intracardial injection of $8 \mathrm{cc}$ of $1 / 10,000$ adrenalin and systolic blood pressure rose from 52 to 140 and then remained at $110 / 80^{\circ}$ The operation was completed and total elapsed time from induction was 5 hours, with $\mathrm{O}_{2}$ adminıstration only, after cardiac ariest occurred

\section{Postoperatuvely}

10 minutes after completion of oseration, theie was generalized clonic convulsion with extensor ngidity present, pupils cilated, fixed (Arfonad)

30 minutes corneal reflexes present, plantar response absent

1 hour nigidity decreasing, moving arms spontaneously, biting endotracheal tube and becoming very restless.

2 hours very restless, sodium luminal $120 \mathrm{mg}$ intıamuscularly

3 hours extubated, patient quieter with less movement and less rigidity, but resists flexion, plantar 1esponse bilaterally extensor, blood pressure 100-110/75-80, pupils smaller and reacting to light, temperature $101(\mathrm{R})$, blood sugar $200 \mathrm{mg}$ per cent

24 hours drowsy (sodium luminal), talking, moderate onentation, recognized relatives, urine output $700 \mathrm{cc} / 24$ hours

48 hours fully conscious, remembers events up to going to the operating room

1 week appéars well, chest clear, ECG repeatedly normal and no mental change according to relatives

3 months completely well

9 months. completely well, no mental change

\section{Discussion}

The use of induced hypotension in surgery has not retained its popularity in most centres, in the ten years since introduction by Gillıes and Griffiths (2) In this centre, induced hypotension is reserved for certain types of major surgery, 
where it is thought to be beneficial to both surgeon and patient. The above two cases-appear to fall into that category. Both patients were physically fit, and suitable candidates to sustain a lowered blood pressure, although one might question the advisability of the technique in patients with haemoglobin of 76 and 75 per cent respectively. Cardiac arrest represents a 1.3 per cent occurrence in this writer's personal series of induced hypotension. I wish to thank my surgical colleagues, Drs. E. H. Botterell and J. E. Mullens for permission to report these cases.

\section{REFERENCES}

1 LrtTle, D M Controlled Hypotension in Anesthesia and Surgery. Am Lecture Series Springfield, Ill C C Thomas (1956).

2. Griffiths, H W C, \& Gilliles, JohN Thoraco-lumbar Splanchnicectomy and Sympathectomy Anaesthetic Procedure Anaesthesia 3 134 (1948) 